\title{
Bartholin Gland Carcinoma
}

National Cancer Institute

\section{Source}

National Cancer Institute. Bartholin Gland Carcinoma. NCI Thesaurus. Code C9055.

A carcinoma that arises from the Bartholin gland. It usually affects women over fifty and presents with enlargement of the Bartholin gland. Various histologic subtypes have been identified and include adenocarcinoma, squamous cell carcinoma, adenoid cystic carcinoma, adenosquamous carcinoma, transitional cell carcinoma, and small cell carcinoma. 